\title{
Espiritualidade e Bíblia Integração e humanização geradas por um Livro vivo
}

\author{
Spirituality and Bible \\ Integration and humanization generated by a living book
}

Lúcia Pedrosa-Pádua

\section{Resumo}

A relação entre espiritualidade e Bíblia não se resume à relação com um livro, mas com o "livro vivo", Cristo, como pode ser visto nos testemunhos dos místicos e bíblico, bem como na reflexão teológica. A experiência bíblica, porque conduzida pela lógica da Encarnação, gera uma espiritualidade integradora e humanizadora. Infelizmente, muitos momentos na história da espiritualidade foram carentes da novidade bíblica, resultando na associação da espiritualidade a uma vida exclusivamente interior ou ao que é não material. A experiência do Espírito na Bíblia demonstra que tais associações são infundadas. Ao contrário, a "vida no espírito" integra todas as dimensões humanas, gera vida e solidariedade concreta. Nosso tempo, com seus desafios, traz a novidade do Espírito, que é preciso ver e acolher, para que se mantenha vivo e libertador o diálogo com as Sagradas Escrituras.

Palavras-chave: Bíblia; Encarnação; Espiritualidade integradora; Mística.

\section{Abstract}

The relationship between spirituality and the Bible is not just the relationship with a book, but with the "Living Book". Christ, as seen in the testimony of mystics and biblical testimony, as well as in the theological reflection. The biblical experience, because it is conducted by the logic 
of the Incarnation, generates an integrative and humanizing spirituality. Unfortunately, many times the history of spirituality was marked by the absence of the biblical novelty, and, as a result, spirituality was associated exclusively with interior life or with what is immaterial. The experience of the Spirit in the Bible shows this type of association to be unfounded. On the contrary, "life in the spirit" integrates all human dimensions, generates life and concrete solidarity. The challenges of our time should lead us to be open to the newness of the Spirit, which must be seen and accepted, so that the dialog with the Sacred Scripture remains alive and liberating.

Keywords: Bible; Incarnation; Integrative spirituality; Mysticism.

\section{Introdução}

Estariam a espiritualidade e a Bíblia separadas em dois mundos? Podemos dizer que, em alguns momentos históricos, dos quais o presente não pode ser totalmente excluído, sim, com grande prejuízo à vida cristã. Ao denunciar, em meados do século XX, o divórcio entre teologia e espiritualidade, Von Balthasar chegou a descrever a teologia como "ossos sem carne" e, como "carne sem ossos", toda espiritualidade, mística e literatura piedosa sem substância. E fez uma proposta programática para a vida cristã: a de fechar esta ferida aberta com as reservas de sua própria experiência espiritual autêntica. ${ }^{1}$ Por isso, ao darmos relevo, neste estudo, ao testemunho dos místicos e à experiência do Espírito atestada nas Sagradas Escrituras, intencionamos contribuir para "fechar esta ferida".

O objetivo deste artigo é aprofundar na relação entre espiritualidade e Bíblia sob diversos aspectos. Ressaltamos a importância do fato da Encarnação e da lógica encarnatória do Espírito para uma espiritualidade realmente integradora e humanizadora.

Após apontarmos as consequências da separação entre espiritualidade e Bíblia, destacaremos algumas características de um testemunho místico fortemente marcado pela experiência bíblica, o de Santa Teresa de Jesus. Em seguida veremos como a Palavra não é exterior ao sujeito e à realidade, pela presença do Espírito em tudo. Segundo estes pontos de partida, a única opção verdadeiramente cristã e bíblica é a espiritualidade integral, que abrange a vida inteira.

\footnotetext{
${ }^{1}$ Von BALThaSAR, H. U. Teologia y santidad. In: Ensayos Teologicos. Vol. I: Verbum Caro, Madrid: Ediciones Cristiandad, 1964, p. 235-268.
} 
Objetivando construir um itinerário que demonstre o caráter integrador da espiritualidade, traçaremos então algumas linhas da história da espiritualidade, constatando a carência da novidade bíblica (e, portanto, da perspectiva integradora) em vários momentos. Por isso, vimos a importância de aprofundar na experiência do Espírito no testemunho bíblico: o Espírito é força de vida e amor e não se dissocia da existência de Jesus, Deus encarnado. Ele afirma a Espiritualidade em sua proposta integradora: vida no Espírito. Finalizamos apontando a necessária escuta das experiências do Deus da vida em nossa contemporaneidade, que convidam à abertura das Escrituras sob o signo do Espírito.

\section{Separar espiritualidade e Bíblia é retirar a novidade de Cristo da vida cristã}

O grande problema da separação entre espiritualidade e Bíblia é que não há separação apenas de um livro, mas da Palavra viva, a Presença percebida na história da salvação, de quem a Bíblia fala e a quem leva: o Cristo vivo que faz viver. Separar espiritualidade e Bíblia é retirar da vida espiritual a novidade de Cristo, Deus encarnado, gerado do Espírito e que gera vida para nós. É separar-se da imagem de Deus que a Encarnação vem trazer. É alienar-se de Cristo como "um acontecer daquilo que significamos com o termo "Deus", como Palavra que aconteceu no existir humano. Tendo ressoado na criação (S1 19[18]), nos profetas (Hb1,1), ela ressoou definitivamente em Jesus. ${ }^{3}$

Fora da lógica da Encarnação, a espiritualidade fica ao sabor da "doutrina comum" sobre Deus, frequentemente dualista, que justapõe espírito e matéria. ${ }^{4}$ Deus, segundo esta noção comum, é associado ao que é imaterial, bem como ao atendimento de nossas necessidades a partir de fora da pessoa, da história e do cosmos. Tal noção desconsidera Deus em seu extraordinário compromisso com a vida humana, a partir de dentro das realidades. Facilmente, a doutrina comum de Deus gera uma espiritualidade que se reduz ao "não material" ou se perde em um contínuo "pedir a Deus ou aos santos" que, muitas vezes, não afeta o núcleo da vida nova que Cristo oferece e que o cristão é chamado a viver.

\footnotetext{
${ }^{2}$ KONINGS, J. “Interpretar a Bíblia aos cinquenta anos do Concílio Vaticano II”. Perspectiva Teológica 44 (2012) 237-256. Aqui, p. 244.

${ }^{3}$ Cf. Ibidem, p. 239-240.

${ }^{4}$ Remeto ao meu estudo: Evolucionismo e espiritualidade: contribuições da mística para uma revisão da imagem de Deus, na obra: GARCIA RUBIO, A. e AMADO, J. P. Fé cristã e pensamento evolucionista. Aproximações teológico-pastorais a um tema desafiador. São Paulo: Paulinas, 2012, p. 221-253, que aborda os temas das espiritualidades destrutivas e da revisão da imagem de Deus oferecida pelos místicos.
} 
Hoje, a teologia espiritual volta às fontes bíblico-patrísticas, para afirmar o necessário processo integrador entre espiritualidade e Bíblia.

\section{O testemunho místico: o "livro vivo"}

Iniciamos este artigo com o testemunho de Santa Teresa de Jesus, Doutora da Igreja. Em 1559, ela se vê diante da proibição da leitura de vários livros, entre eles a Bíblia. Trata-se do Indice de Libros prohibidos, ou Índice de Valdés. ${ }^{5}$

O Índice buscava conter erros e doutrinas que julgava escandalosos e desconfiava do uso da Escritura, especialmente por mulheres e por pessoas sem letras. Estão no Índice 13 edições consideradas errôneas da Bíblia latina, 11 do Novo Testamento e todas as versões do Antigo e Novo Testamento em língua vulgar ou castelhana. Permaneceram apenas as Bíblias em grego, hebraico, caldeu e a Vulgata latina. ${ }^{6}$

Como podemos imaginar, houve um forte impacto depressivo entre editores, livreiros e autores de livros de espiritualidade. ${ }^{7}$ Mas o Índice atingiu, de forma especial, os leigos, o povo simples que não sabia o latim e, entre eles, as mulheres. E os atingiu em vários sentidos: o primeiro, material, reduzindo as possibilidades de acesso às Sagradas Escrituras; o segundo, pela via simbólica, evidenciando o preconceito e temor com relação à leitura que a mulher e os simples pudessem fazer delas; o terceiro, associando a leitura bíblica à heresia.

Um testemunho de época chegou a retratar aquele momento como um retrocesso para todos, "tempos em que se predica que as mulheres tomem sua roca de fiar e seu rosário, e não se dediquem mais às devoções".

Quando Santa Teresa escreveu o seu Livro da Vida, em 1565, seis anos após o Índice de Valdés, teceu apenas um discreto, porém, sentido comentário rememorativo: "Senti muito quando se proibiu a leitura de muitos livros em castelhano, porque alguns me deleitavam, e eu não poderia mais fazê-lo, pois os permitidos estavam em latim."

\footnotetext{
${ }^{5}$ Cf. TELLECHEA, G.I. "La censura inquisitorial de Biblias de 1554". Anthologica Annua 10 (1962) 89-142; PABLO MAROTO. D. "Santa Teresa y el protestantismo español”. Revista de Espiritualidad 40 (1981) 277-309, aqui p. 289; ANDRES MARTIN, Melquíades. La Teología Española en el siglo XVI. Madrid: BAC, 1977, v. II, p. 615.

${ }^{6}$ Cf. ANDRES. La teología española..., p. 616-617.

${ }^{7}$ Cf. Ibidem, p. 542 - 625.

${ }^{8}$ NAVARRO sj. Pedro. MHSI, Epistolae Quadrimestres VI p. 354. Apud. ANDRES. La teología española..., p. 626.

${ }^{9}$ TERESA DE JESUS. Livro da Vida (V 26,5). In: TERESA DE JESUS. Obras Completas [texto estabelecido por Tomás Álvarez]. São Paulo: Carmelitanas/Loyola, 1995, p. 171.
} 
A sorte de Teresa, no entanto, é que uma voz interior e misteriosa mística -, encheu-lhe de confiança e lhe assegurou: "não sofras, eu te darei um livro vivo." ${ }^{10}$ Foi o início de uma vivência ainda mais profunda da relação com Cristo, livro vivo. Teresa fez, deste modo, radical passagem da letra ao espírito. Realizou, em admirável experiência, a finalidade da Escritura, que é o encontro com o Cristo vivo, a própria vida, em abundância (cf. Jo 10,10).

$\mathrm{Na}$ vida cotidiana de Santa Teresa, o substrato possibilitador da relação com Cristo, livro vivo, já estava posto. Era a sua forma de leitura bíblica. Não uma leitura conceitual, que buscava apenas "entender" o significado da Bíblia; tampouco uma leitura mecânica ou exterior. Tratava-se de uma leitura vital, na qual a Palavra de Deus iluminava sua situação concreta. Os atuais estudos da obra teresiana revelam como ela fez realidade a relação entre Palavra e vida. A Palavra "é para a vida, ou melhor, para o humano vivente. E se não é assim, deixa de ser Palavra Viva". ${ }^{11}$

Não se pode afirmar que a cultura bíblica da Santa fosse extensa. No entanto, sua inteligência e experiência da Bíblia, inclusive sua vivência sobrenatural dela, são extremamente significativas. Teresa é um testemunho vivo de que é possível desenvolver uma compreensão profunda das Escrituras, mesmo com um pequeno nível de informações. ${ }^{12}$ Talvez esta compreensão tenha sido possibilitada pela tendência de Teresa a interiorizar a Bíblia. Ela considerava seu ser, sua pessoa, como uma espécie de "terra santa", onde se realizam os mistérios de Deus e de Cristo. ${ }^{13}$ A Bíblia para Teresa não era uma Palavra exterior, mas luz, chão e horizonte para sua própria interioridade e para o seu próprio viver. Seu diálogo com o Jesus dos Evangelhos era a base de sua oração e de seu magistério.

A experiência e a obra de Santa Teresa estão profundamente tecidas por esta experiência da Bíblia, que a inspirou e apoiou, emprestou-lhe palavras e um mundo sem fim de sugestões. Enfim, agiu em sua vida como Palavra de Deus.

\footnotetext{
${ }^{10}$ Ibidem. Para um comentário sobre a "sorte" de Teresa cf. ALVAREZ, T. "Santa Teresa maestra de vida espiritual”. In: Estudios Teresianos. v.III. Burgos: Monte Carmelo, 1996, p. 333-351, aqui, p. 335 (publicado por primeiro em: Confer 80 [1982] 685-702).

${ }^{11}$ HERRAIZ, Maximiliano. "Biblia y espiritualidad teresiana”. Monte Carmelo 88 (1980) 305-334, p. 310. Trad. nossa.

${ }^{12}$ Cf. LLAMAS, Román. "Santa Teresa y su experiencia de la Sagrada Escritura”. Teresianum 33 (1982) 447-513 e também, do mesmo autor: "Teresa de Jesús, testigo de la Palabra de Dios". Revista Teresa de Jesús: Temas Teresianos. Ávila, 1987, p. 67-78. Número especial.

${ }^{13}$ CASTRO, Secundino. "Mística y cristología en Santa Teresa”. Revista de Espiritualidad 56 (1997) 75-117, aqui p. 88.
} 
Sua experiência do Cristo - livro vivo - foi o aprofundamento místico da relação que estabelecera com o Jesus dos Evangelhos. Uma história de diálogo, amizade e amor que a acompanhou nos momentos fáceis e nos graves momentos exigidos por sua ação profética de escritora, fundadora e mestra da vida espiritual, até o fim de sua vida. Muitos, na Igreja e também fora da comunidade eclesial, se beneficiaram e beneficiam com esta experiência, ao longo destes quase quinhentos anos que nos separam do nascimento de Teresa. De forma misteriosa, e graças ao seu magistério, eles participam da experiência teresiana.

\section{Interioridade humana e exterioridade da Palavra: relação dina- mizada pelo Espírito}

O testemunho místico de Santa Teresa nos abre para uma pergunta: qual a relação entre a interioridade humana e a exterioridade da Palavra? A Palavra conformaria a experiência cristã a partir de fora, arbitrariamente, contra a liberdade do próprio sujeito? A tradição respondeu a esta pergunta em termos dialógicos entre a Palavra e a pessoa, diálogo possibilitado pelo Espírito.

A vida segundo o espírito - espiritualidade - está sempre referida ao Mistério e à Presença. Mistério que se manifesta mantendo o seu segredo e sua Presença, que nunca são totalmente compreendidos ou plenamente dados. Esta referência ao Mistério não se realiza sem mais, na interioridade do sujeito, por mais profunda que seja esta interioridade. A mútua referência requer mediações, exige um dinamismo relacional. E este se dá pelo diálogo estabelecido pela Palavra. A Palavra desperta a profundidade humana e faz vislumbrar sempre algo mais - em si mesmo e na Palavra. Ela faz caminhar.

Assim, há uma mútua referência entre o sujeito, com sua interioridade, e a Palavra que o provoca, aparentemente exterior ao sujeito. Mas, na Palavra se encontra o mesmo mistério presente no humano. No símbolo de Orígenes, elas - interioridade humana e Palavra - são como dois livros que se leem e que se comentam um ao outro.

Vejamos isto mais de perto.

$\mathrm{Na}$ patrística, Orígenes afirmava que há uma conaturalidade entre a Escritura e a alma. ${ }^{14}$ Não devemos entender a alma como uma parte da pessoa, separada e independente do corpo, mas como a integridade da pessoa, aces-

\footnotetext{
${ }^{14}$ Cf. MARTÍN VELASCO, J. El fenómeno místico. Estudio comparado. Madrid: Trotta, 1999, p. 219-220, em que mostra os estudos de H. de Lubac sobre a relação entre a Escritura e a pessoa em Histoire et Esprit (1950).
} 
sada a partir de sua interioridade. Por que esta conaturalidade? Porque ambas são um templo em que Deus reside. Na pessoa, como Logos; na Escritura, como Palavra. Ambas são um paraíso onde Deus passeia (cf. Pr 8,30-31). Ambas, pessoa e Palavra, expressam-se mutuamente e se reencontram uma na outra. Elas se esclarecem reciprocamente, se comentam. Quanto mais penetro no sentido da Escritura, mais penetro no sentido do meu ser. E o contrário também acontece: cada vez que penetro o sentido do meu ser, mais abro sentidos nas Escrituras. Quanto mais abro o meu poço, mais abro o poço das Escrituras, pois o Espírito, água viva, jorra em mim e na Escritura.

Esta relação se enriquece se nos lembramos do Livro vivo, Cristo. Ao se aproximar da Palavra, a pessoa se abre ao Cristo, Palavra feita carne. E o encontro com Cristo provoca uma revelação da pessoa a si mesma. A pessoa se encontra e se transforma naquele à imagem de quem foi criada. O Concílio Vaticano II remete a esta relação ao afirmar que "o mistério do homem só no mistério do Verbo encarnado se esclarece verdadeiramente" (GS 22). Isto se faz experiência na relação com a Palavra.

Na obra poética de Santa Teresa encontramos um refrão que expressa belamente esta realidade de mutua relação. Nela, acontece um diálogo em que Cristo diz à pessoa: "Alma, buscar-te-ás em mim, e a Mim buscar-me-ás em ti." ${ }^{15} \mathrm{O}$ Cristo, Palavra viva, não é uma realidade exterior, mas interior à pessoa, que é criada à sua imagem. Pelo diálogo com Cristo, possibilitado pela Sagrada Escritura, a relação pessoa-Cristo se estabelece, gerando dinâmicas transformadoras da vida pessoal, das relações, do atuar da pessoa. Uma vida que se renova.

Assim sendo, há uma relação dialógica e de liberdade entre experiência espiritual e Palavra. Mas a experiência espiritual não significa confinamento no interior humano, porque ela é traduzida, justamente porque é diálogo, em vida transformada. A relação entre vida (e vida plena, com sentido, justiça, liberdade e beleza) e Palavra, sempre de vida e de liberdade, é fundamental para a espiritualidade cristã.

\section{A experiência espiritual de um povo e a Palavra - dinamismo de vida}

A espiritualidade latino-americana valorizou esta relação entre Palavra e vida de maneira especial. Gustavo Gutiérrez explorou a metáfora do poço em sentido também comunitário, em Beber em seu próprio poço: a Escritura

15 TERESA DE JESUS. Poesias. VIII: Buscando a Deus. In: TERESA DE JESUS. Obras Completas, p. 979. 
abre sentidos de vida à experiência não apenas pessoal, mas de um povo que luta pela vida; e a experiência de vida (pessoal e de um povo, com suas celebrações e lutas), como um poço, é fonte para se abrir sentidos à Escritura, um ponto de partida para se compreender as ações e palavras de Jesus. ${ }^{16}$

A experiência de Deus é sempre experiência propulsora de vida libertada e de esperança. É experiência de Deus como justiça e santidade, próximo e fiel, amor e perdão, amigo da vida. No NT, Jesus se apresenta como a vida (cf. Jo 14, 6). Ele veio para que todos tenham vida, e vida em abundância. Ele é Luz que conduz à vida $\left(J_{0} 8,12\right)$. Entrar no Reino é entrar na vida. E vida que implica conversão à justiça do Reino (Mt 5-7). Na ressurreição, Jesus não pode ser procurado entre os mortos (cf. Lc 24, 5). Para Paulo, a vida nova da Ressurreição é a pedra angular da sua mensagem (cf. 1Cor 15, 14). Os cristãos devem anunciar a Ressurreição, que Deus é um Deus de vida, da vida e para a vida. Ele mantem viva a esperança de um povo porque Deus é vida. ${ }^{17}$

Assim sendo, interioridade humana e Palavra não são duas realidades artificialmente unidas. Sua relação é forte e favorável precisamente porque ambas trazem, intrinsecamente, o selo do Espírito do Cristo vivo, que dinamiza a vida. Da mesma forma, as realidades dos povos, que buscam mais vida, não são unidas artificialmente com a Palavra, pois, nelas, age o mesmo Espírito.

\section{Espiritualidade: uma história de dualismos e carente da novidade bíblica}

Infelizmente, na história da espiritualidade, é bem conhecido que nem sempre a integração entre Palavra e vida esteve presente. Ao contrário, prevaleceu a contraposição e inimizade do espírito à matéria, à natureza, ao sensível. Esta contraposição emergiu bem cedo, no cristianismo, como força poderosa, a partir das correntes platônicas e neoplatônicas. ${ }^{18}$ Correntes gnósticas (séc. II e III) acentuaram a supremacia do "espírito" sobre os aspectos materiais da vida.

Contudo, no período bíblico-patrístico é preciso mencionar o esforço em ser fiel à Bíblia e associar a espiritualidade à vida conduzida pelo Espírito Santo. Em sua reflexão, os Padres haviam desenvolvido os diversos aspectos da vida cristã, segundo vários níveis de compreensão da Palavra de Deus. Encontraram

\footnotetext{
${ }^{16}$ Cf. GUTIERREZ, G. Beber em seu próprio poço. Itinerário espiritual de um povo. São Paulo: loyola, 2000, p. 52-54.

${ }^{17}$ Idem. O Deus da vida. 3. ed., São Paulo: Loyola, 2004.

${ }^{18}$ Cf. GARCIA RUBIO, A. Unidade na pluralidade. O ser humano à luz da fé e da reflexão cristãs. 4. ed., São Paulo: Paulus, 2006, p. 97-101.
} 
diversos sentidos da Escritura: além do sentido literal, destacaram um sentido típico (próximo ao sentido doutrinal), um sentido anagógico (próximo ao sentido místico), um sentido moral e um sentido propriamente espiritual. Esta forma de fazer teologia prolongou-se ainda na tradição monástica. ${ }^{19}$

Mas esta noção se alterou no período medieval. No final do séc. XII e ao longo do XIII, o discurso teológico tendeu a assumir uma forma mais científica, assumindo a filosofia aristotélica que entrava na cultura da época. A teologia se dividiu em tratados diversos. Tendeu-se a eliminar o coeficiente afetivo e pessoal, a dimensão exortativa, a fim de tratar de maneira objetiva e científica os problemas postos pela fé. Com isso, a espiritualidade deixou de receber da teologia as inspirações bíblicas. ${ }^{20}$

Espiritualidade passou então a significar a vida sobrenatural (o que provém de Deus, não da natureza) e aquilo que é imaterial, em contraposição e exclusão às realidades materiais e tangíveis, corpóreas e sensíveis. Separada das lutas do mundo e do desfrute ou prazer. O mundo da vida será considerado negativamente. ${ }^{21}$

Surge o desejo de enfatizar a vida interior. O movimento espiritual da devotio moderna (séc. XIV-XV), representado pela obra Imitação de Cristo, manifesta como a vida interior, o diálogo íntimo com Jesus no segredo da oração e da comunhão eucarística tornam-se os elementos quase exclusivos da espiritualidade, longe e quase opostos às especulações filosófico-teológicas. ${ }^{22}$ Acontece um movimento de redução, ainda não superado, da espiritualidade à interioridade.

Importantes místicos do século de ouro espanhol, como Santo Inácio de Loyola, São João da Cruz e Santa Teresa procurarão maior base bíblica, tendo mesmo algumas relações com a forma patrística de ler a Bíblia, mas nem sempre foram bem compreendidos por seus leitores, nesta intencionalidade. Inseridos no movimento de sua época, seguem no argumento de integrar a vida cristã a partir da vida interior.

A partir do século XVII, concretiza-se a redução da espiritualidade à vida interior, ao relacionamento afetivo com Deus ou aos fenômenos místicos extraordinários vividos por pessoas igualmente extraordinárias. Devido a isto, em muitos círculos teológicos o termo espiritualidade passa a ser depreciado,

\footnotetext{
${ }^{19}$ BERNARD, C. A. Introdução à Teologia Espiritual. São Paulo: Loyola, 1999, p. 41-52. ${ }^{20}$ Ibidem.

${ }^{21}$ SCHNEIDERS, Sandra. "Theology and spirituality: strangers, rivals or partners?" Horizons 13/2 (1986) 253-274.

22 BERNARD, op. cit.
} 
para renascer no fim do século XIX e no século XX. Aí, vai designar a vida espiritual enquanto experiência vivida, privilegiando os múltiplos estágios interiores como a ascese, a mística, o desenvolvimento dos dons do Espírito, a direção espiritual, etc. ${ }^{23}$

Coube ao Vaticano II a renovação da espiritualidade com a convocação da volta às fontes. Para não ser confundido com o sentido dado na primeira metade do século XX, o termo espiritualidade foi evitado nas grandes Constituições do Concílio! No entanto, a conclamação a uma urgente volta às Sagradas Escrituras, a afirmação da realidade da vida associada ao mistério de Cristo e a explicitação da santidade como vocação universal, associada ao amor, mostram que a espiritualidade, como vida no Espírito de Cristo, está bem presente no texto conciliar. Em outras palavras, o Concílio retornou à intrínseca relação entre espiritualidade e Bíblia, espiritualidade e Cristo Livro vivo nas palavras de Teresa de Jesus.

A espiritualidade presente na proposta conciliar é integradora. Mas, ainda hoje, é possível encontrar, em diversos grupos, a presença das duas principais reduções que a espiritualidade sofreu ao longo dos séculos: redução à vida interior ou contemplativa (em oposição e exclusão à vida em suas múltiplas dimensões) e redução ao imaterial (em oposição e exclusão à dimensão material e corpórea da existência).

Esta espiritualidade reduzida à interioridade e à imaterialidade está em evidente contraposição à proposta bíblica da vida no Espírito, como veremos a seguir. Para isso, veremos como se dá a experiência do Espírito na Bíblia.

\section{A experiência do Espírito no testemunho bíblico: o Espírito é força de vida e amor e não se dissocia da existência de Jesus, Deus encarnado}

Não é intenção deste artigo discorrer sobre o Espírito Santo na história da salvação, apenas destacar alguns aspectos que mostram a experiência do Espírito como aquela que faz viver, em sentido integral. Assim, destacaremos: a presença e ação do Espírito a partir de dentro da criação, da história e das pessoas; a presença e ação do Espírito na vida de Jesus; a presença e ação do Espírito na vida das comunidades.

${ }^{23}$ Cf. SECONDIN, B.; GOFFI, T. (Orgs.). Curso de Espiritualidade: experiência, sistemática, projeções (trad. B. Brod). São Paulo: Paulinas, 1994, p. 13. 
Na criação, o Espírito (ruah, em hebraico, palavra feminina; pneuma, em grego) não se contrapõe à matéria ou ao corpóreo. Ao contrário, está dentro dela como energia em movimento, que cria e recria. É sempre energia de vida que doa vitalidade a toda a criação e, especialmente, à pessoa. Ele está presente desde o início (Gn 1,2). É a ruah de Javé. Na primeira e mais antiga acepção, espírito indica o sopro, o ar, o vento. Uma das forças generativas, vitais (o fogo, a terra, a água, o ar), que traz consigo energia. Ruah não se identifica com estes fenômenos, mas traduz a força e energia em movimento. Está dentro do mundo, da criação, das pessoas, sem se confundir com elas. $\mathrm{O}$ vento, o sopro e outros símbolos tornam visível a energia misteriosa que atua neles. É assim, como vento impetuoso que movimenta as pessoas e a comunidade, que o Espírito vem descrito em Pentecostes (At 2,1-2).

A acepção de ruah também está ligada ao fenômeno da respiração, fôlego, hálito, alento. Princípio e sinal de vida (Gn 7,22; S1 104,29-30). O Evangelho de João nos mostra que o Espírito é livre, ninguém sabe de onde vem ou para onde vai (Jo 3, 8; cf. Ecl 8, 8). É energia de viver, força de ânimo (cf. Gn 6, 17; 7, 15).

O Espírito está presente na história. É imprevisível, se observamos os profetas (cf. Os 9,7; e também Jz 14, 6.19; 15,14). É associado ao Messias, segundo as promessas messiânicas. O próprio termo Messias significa "ungido", sinal de que o Espírito vem sobre ele para uma missão (Is 11,1-2). O Messias é um Messias servidor, como mostra Is 42,1.6-7: "Pus sobre ele o meu espírito, ele trará o julgamento às nações"... "para o serviço da justiça" ... "a fim de abrir os olhos dos cegos, a fim de soltar do cárcere os presos, e da prisão os que habitam nas trevas". No NT, Lc 4 resumirá: "anunciará a Boa Nova aos pobres...". Surge a promessa de que a vinda do Messias transformará o povo. A ruah virá a todos. Difundirá vida, paz, direito, justiça, felicidade, liberdade (cf. Is 32,15-20). Espírito e serviço da justiça e aos pobres estão interligados.

${ }^{24}$ Cf. CONGAR, Y. Revelação e experiência do Espírito. 2a ed. São Paulo: Paulinas, 2009, p. 17-30; CODINA, V. "Não extingais o Espírito" (1Ts5,19). Iniciação à Pneumatologia. São Paulo: Paulinas, 2010, p. 36-44; GARCIA MATEO, R. Lo Spírito Santo nella vitta spirituale. Roma: Pontificia Università Gregoriana, 2001, [ap.], p. 1-3 e PEDROSA, Lúcia. "Evangelizar uma cultura violenta". In: Violência, sociedade e cultura. Cadernos CERIS. Vozes/ Paulus/Loyola/ Paulinas/CERIS, 2001, p.35-56. 
O Espírito é ação de Deus que comunica $(\mathrm{S} 133,6)$ e recria a vida. $\mathrm{O}$ profeta Ezequiel diz que a ruah não só escreverá a lei no coraçao, mas recriará o coração e o espírito do seu povo (cf. Ez 36, 26-28). Esta renovação restitui a vida aos ossos secos (Ez 37,1-11).

$O$ Espirito é força recriadora diante do pecado e da violência. A tradição viu na pomba um símbolo do Espírito, que busca caminhos de paz. Deus renova a aliança com Noé, o justo. A pomba, com o ramo novo de oliveira, traduz a promessa de reconstrução $(\mathrm{Gn} 8,11)$. No NT, no relato do batismo de Jesus (Lc 3,22), a pomba mostra que o Espírito que o conduzirá é de paz e reconciliação. Também Pentecostes é uma experiência recriadora. Abre caminhos de união, comunhão e diálogo, paz. Pentecostes recria a fé dos discípulos, que estava morta.

Joel anuncia a efusão do Espírito Santo em todo o povo, sem distinção de sexo, idade e classe (J13,1-3). No dia de Pentecostes, Pedro reconhecerá o cumprimento deste oráculo (cf. At 2,15-22). Os livros sapienciais nos mostram que o Espírito está em todos, não se limita ao rei, aos profetas e escritores, pois também está no povo, nos artistas, na sabedoria popular de outros povos e culturas.

\section{O Espírito e Jesus ${ }^{25}$}

O Espírito Santo não se dissocia de Jesus - a mesma ruah está em Jesus. A pessoa de Jesus pressupõe o agir do Espírito de Deus, como se vê desde a anunciação (Lc 1,35 - "o Espírito Santo virá sobre ti e o poder do Altíssimo vai te cobrir com a sua sombra"). Os que se aproximam de Jesus estão sob a influência do Espírito, enchem-se do Espírito. O evangelista Lucas, especialmente, ressalta esta ação do Espírito naqueles que se encontram no raio da presença de Jesus (Maria: Lc 1,41; Zacarias: Lc 1,67; pastores: Lc 2,9; Simeão: Lc 2,25-35; Ana: Lc 2,36-38).

É clara a ação do Espírito no Batismo, que declara Jesus o Messias, o ungido pelo Espírito (cf. Mt 3,16-17), tal como é anunciado em Is 42, o servo de Javé, que Mateus cita textualmente (12,18-21). Para cumprir sua missão

\footnotetext{
${ }^{25}$ Seguiremos, neste ítem, a CONGAR. op. cit., p. 31-39; CODINA. op. cit., p. 44-61; GARCIA MATEO. op.cit., p. 3-9; LADARIA, Luis F. El Dios vivo y verdadero: El misterio de la Trinidad. Salamanca: Secretariado Trinitario, 1998, p. 93-105; ROVIRA BELLOSO, J. M. Tratado de Dios, uno y trino. Salamanca: Secretariado Trinitario, 1998, p. 485ss e MESTERS, C. Descobrir e discernir o rumo do espírito: uma reflexão a partir da Bíblia. In: FABRI DOS ANJOS, Márcio (org.). Sob o fogo do Espírito. São Paulo: Paulinas/SOTER, 1998, p. 81-112.
} 
como Messias servidor, Jesus recebe um impulso definitivo, nas tentações (Mt 4,11; Lc 4,13).

A atividade evangelizadora de Jesus se inicia sob a ação do Espírito (Lc 4,14-30; cf. Is 61,1-2). Os milagres devem ser entendidos como manifestação do poder de Deus em Jesus por meio do seu Espírito (cf. Lc 7,22; Mt 12,28), sinais do Reino de Deus que Jesus anuncia e realiza em si. Desta forma, um critério da ação do Espírito é o amor, é "fazer o bem", de forma especial aos pobres e necessitados. Quando Jesus louva, ora, agradece a Deus é sempre na presença do Espírito (Lc 10,21).

Mas, para que seja possível reconhecer o Espírito, é necessário abrir-se a ele. O fechamento é o sentido da "blasfêmia" contra o Espírito Santo (Mt 12,31 e paralelos). Assim, a resposta ao Espírito depende da abertura da pessoa a ele. Ao contrário, o fechamento ao Reino, ao bem e ao perdão cria um estado pessoal e relacional lastimável.

O evangelho de João é especialmente rico para nos revelar a relação entre Jesus e o Espírito. A missão de Jesus é que todos tenham vida, e vida em abundância (Jo 10,10) - isto só é possível no contato com a fonte de água viva (cf. Jo 4,14). No encontro com Nicodemos, Jesus diz que é preciso renascer da água e do Espírito, como condição indispensável para o seu Reino (Jo 3,5-6). À samaritana, Jesus promete a "fonte de água viva" - trata-se do Espírito, vida e renascimento em Deus, pelo encontro com Jesus Cristo vivo.

O Espírito é qualificado como dom (Jo 7,38-39). No discurso depois da ceia (Jo 14,16-17), Jesus especifica o Espírito que o Pai enviará por Cristo, o Paráclito - o Espírito Santo. O Paráclito significa defensor, advogado, redentor, aquele que resgata, redime, liberta, salva. Trata-se de outro Paráclito, pois, conforme 1Jo 2,1, Jesus ressuscitado é também advogado.

O Espírito permanece (Jo 14,16-18), ensina e recorda, "leva à compreensão plena da mensagem de Jesus" ${ }^{\text {"26 }}$ (Jo 14,26), defende nos tribunais (Mc 13,11) e nos grandes julgamentos da história (Jo 16,8).

O Espírito possui especial relevo no mistério pascal. João ressalta que Jesus vem do Espírito, e que dará o Espírito com sua glorificação pascal, que começa com a cruz. A hora pascal em João é a hora de Jesus e a hora do Espírito. Na morte de Jesus, João nos diz que ele entregou o Espírito (Jo 19,30), que significa transmitir e comunicar o Espírito.

${ }^{26}$ CODINA. op. cit., p. 54. Itálico nosso. 
Há uma relação entre a partida de Jesus e a efusão do Espírito, em João. Nesse Evangelho, não se fala nem de Ascensão, nem de Pentecostes. À tarde do mesmo dia da ressurreição, Jesus doa seu Espírito, pelo qual poderão oferecer o perdão: "recebei o Espírito Santo" (Jo 20, 22). Desde o primeiro instante de sua ressurreição Jesus está na glória do Pai e, portanto, é já fonte do Espírito Santo.

Desta forma, temos um critério básico para olhar as comunidades: o Espírito que anima as comunidades é o espírito de Jesus (Jo 14,26; Jo 16,12-14).

A relação entre Jesus e o Espírito vem tratada em particular em Paulo: Rm 8,11: "O Espírito é o Espírito daquele que ressuscitou Jesus dos mortos". Segundo Basílio de Cesaréia, "Jesus imprimiu no Espírito o seu selo"27.

A relação entre Jesus e o Espírito é tão estreita que para Paulo a fórmula "no Cristo" e "no Espírito" são intercambiáveis. O Batismo é realizado em Cristo (G1 3, 27), mas também no Espírito (1Cor 12,13). O Espírito não é apenas poder vivificante de Deus, mas princípio vital do Cristo ressuscitado: "Deus o ressuscitou... exaltado assim pela direita de Deus, ele recebeu do Pai o Espírito Santo prometido e o derramou...” (At 2, 32-33).

O envio do Espírito não se separa de Cristo, antes é complemento da missão de $\mathrm{Cristo}^{28}$. O envio do Espírito é o último mistério do tempo pascal. O Espírito dá aos discípulos a fé em Jesus como Filho de Deus (cf. At 2, 22; $5,30-32$ ) e os leva a viver o maior dom, o amor concreto (1Cor 13), em seguimento daquele que passou a vida "fazendo o bem".

\section{Os sinais do Espírito nas comunidades}

O Novo Testamento nos mostra como a comunidade cristã aprendeu a ler os sinais do Espírito. Trata-se de uma tradução do agir de Cristo para a vida das comunidades. É possível, prestando atenção aos escritos bíblicos, encontrar critérios para discernir esta ação. ${ }^{29}$

O Espírito ressuscita e gera amor e vida. Ele é vida (cf. Rm 8,10) e a força de quem possui o espírito de Cristo é a liberdade para amar (cf. Rm 8,2). O Espírito gera fraternidade, cujo princípio repousa na filiação ( $R m$ 8,15-16), gera "atitude de filiação". ${ }^{30}$ Reconcilia e perdoa (Jo 20,22-23). Acolhe, cura e

\footnotetext{
${ }^{27}$ LADARIA. op. cit., p. 98.

${ }^{28}$ Cf. Concílio Vat II, AG 4, que afirma o envio do Espírito para completar a obra de Cristo.

${ }^{29}$ MESTERS. op. cit., p. 81-112 e ROVIRA BELLOSO. Op. cit., p. 485ss.

${ }^{30}$ LADARIA. op. cit., p. 101.
} 
restaura a integridade: "a outro o único e mesmo Espírito concede o dom das curas" (1Cor 12,9).

O Espírito liberta e gera liberdade: “onde há o Espírito do Senhor, aí há liberdade" (2Cor 3,17). Ele defende (Jo 14,16) e ensina o que dizer diante dos tribunais, "o Espírito vos ensinará o que deveis dizer" (Lc 12,12; Mc 13,11).

$\mathrm{O}$ Espírito congrega, gera comunhão (F1 2,1), leva à unidade e à paz (Ef 4,3). Nele, é possível e desejável a unidade na pluralidade (Ef 2,18). Edifica e constroi a comunidade (1Cor 12,7). A imagem do corpo simboliza uma unidade que mantém e acolhe a diversidade (cf. 1Cor 12,14-31).

O Espírito instrui e ensina a verdade: "Quando vier o Espírito da Verdade, ele vos conduzirá à verdade plena" (Jo 16,13). Ele ajuda a interpretar a Bíblia (2Cor 3,15s; 1Cor 10,1-13) e também a ler a realidade (cf. 2Tm 3,16). Fortalece, dá coragem e envia em missão para anunciar Cristo e seu Reino (At 4,31), fazendo do cristão uma "carta de Cristo" (2Cor 3,3).

O Espírito consola, faz orar (Ef 6,18); ele ora, geme, cria intimidade com Deus - o Espírito se une ao nosso (Rm 8,15-16.26) e faz participar do mistério de Cristo (Rm 6,4-11; 8,11). Mas o Espírito, se não for acolhido, pode ser apagado (1Ts 5,19-20).

Em perspectiva antropológica, o dom do Espírito nos diz que, em toda situação, é possível rezar (Rm 8,26 - gemidos a Deus); em toda situação é possível amar (Rm 5,5 - o Espírito derrama em nossos corações o amor de Deus); em toda situação é possível lutar e esperar como filhos de Deus, pois o Espírito testemunha isso $(\mathrm{Rm} 8,16)$, tirando o espírito de temor e escravidão; em toda situação é possível que uma comunidade se sinta perdoada, reconciliada, capaz de começar de novo, posto que o Espírito Santo é o perdão dos pecados. O Espírito do Cristo Ressuscitado abre caminhos de liberdade, amor e vida.

\section{O testemunho bíblico afirma a Espiritualidade em sua proposta integradora: vida no Espírito}

Otestemunho bíblico, visto acima, desautoriza toda afirmação de que o tempo do Espírito é uma fase mais elevada que a corporeidade, ou que a humanidade. Ao contrário, devemos perceber a relação entre a espiritualidade e a corporeidade (e de forma análoga, a história e o cosmos) de maneira integrada e integradora: o Espírito humaniza, qualificando as relações. Assim, a espiritualidade - "vida 
inteira guiada pelo Espírito Santo"31 - é sempre humanizadora de todas as dimensões do humano e integradora de todas as suas relações.

A espiritualidade não é encontro com o imaterial - esta seria uma forma mais grega do que bíblica de pensar! Espiritualidade entendida como vida segundo o Espírito é o encontro com um furacão, é abertura a uma força irresistível de vida, à própria vida de Cristo! Por isso, é uma forma de estar no mundo. Abrange a dimensão "invisível" das motivações últimas e também o "visível" de um caminho concreto, que compromete a existência de forma total. A espiritualidade atinge corpo e alma, encontra a pessoa em seu trabalho, em seu descanso e em sua oração. Penetra desejos, pensamentos, ações e omissões. Atravessa a dimensão pessoal, comunitária e social. A vida no Espírito não é um acréscimo, ao contrário, ela exprime a própria identidade pessoal dentro de uma situação, em processo libertador ("do espírito"). O caso contrário é o processo idólatra ("da carne"), em nossa história de graça e pecado.

Se na Bíblia a reflexão sobre o Espírito está bem presente, o mesmo não podemos dizer da espiritualidade, palavra inexistente nas Sagradas Escrituras. Mas, os seus conteúdos estão presentes. É o que veremos a seguir.

Paulo reitera o convite a sermos pessoas "espirituais" (pneumatikói): 1 Cor 2,15; G1 6,1; Rm 8,9. ${ }^{32}$ Exorta os cristãos a serem conduzidos pelo Espírito $(\mathrm{Rm} 8,14)$, a andar sob o seu impulso (Gal 5,16). Os cristãos devem estar sob o domínio do Espírito (Rm 8,9).

É a pessoa como um todo - espírito, alma e corpo -, inseparavelmente, que é chamada a viver na santidade: "Que o Deus da paz em pessoa vos santifique totalmente, e que vosso espírito, vossa alma e vosso corpo, sejam perfeitamente guardados para serem irrepreensíveis por ocasião da vinda de Nosso Senhor Jesus Cristo" (1Ts 5,23).

Desta forma, a espiritualidade cristã implica um deixar-se conduzir pelo Espírito, na integralidade pessoal. Igualmente, supõe um estilo de vida, um caminho, uma forma de modelar a existência. Mas sempre lembrando que a vida cristã se desenvolve de forma dinâmica, podendo se concretizar de diferentes maneiras. É processo, itinerário, que supõe idas e vindas, não um processo adquirido e seguro (cf. $\mathrm{Rm} \mathrm{8,22-23).{ } ^ { 3 3 }}$

${ }^{31}$ Exortação Apostólica Pós-Sinodal Ecclesia in America, n. 29. In: http://www.vatican.va/ holy_father/john_paul_ii/apost_exhortations/documents/hf_jp-ii_exh_22011999_ecclesia-inamerica_po.html. Acesso em 01/05/2013.

32 SECONDIN; GOFFI (Orgs.). op. cit., p. 14.

${ }^{33} \mathrm{Cf}$. Ibidem. 
Ela não se opõe à dimensão corpórea ou material. Então, como entender os termos "segundo a carne" e "segundo o Espírito"? É preciso compreender estas acepções paulinas..$^{34}$

Para Paulo, a vida "segundo o Espírito" entra em contraste com a vida "segundo a carne" (em grego, sarx). Evidentemente, não se trata do sentido comum que associa a carne à sexualidade. Vida "segundo a carne" pode ter vários sentidos em Paulo.

Em sentido não conflitivo, vida "segundo a carne" pode significar uma vida segundo critérios puramente humanos e por isso superficiais e ambíguos (2 Cor 10,2: nossa conduta não tem motivos humanos [carnais]; cf. 2,17). Significa também a sabedoria segundo a carne, um saber humano: "não há entre vocês muitos sábios segundo a carne" (1Cor 1,26), ou em 2Cor 1,12: "nos conduzimos não com uma sabedoria humana (carnal), mas pela graça de Deus".

No sentido de "carne de pecado", entra em conflito com o espírito: "entre eles há antagonismo" (G1 5,17). O pecado é dinamismo negativo que age no íntimo da pessoa. Como o ser humano se define em sua relação com Deus, agir segundo a carne seria então entregar a vida a quem não é Deus (cf. Rm 8,3), deixar-se possuir por outro dinamismo. Significa rechaço de Deus, recusa de sua presença no caminhar ( $\mathrm{Rm} 8,5.7 .8 .9$.). Significa fechamento, falsas seguranças, idolatrias e cobiça (Mt 6,24: "não é possível servir a dois senhores"; C1 3,5; Ef 5,5). E assim, entrar em dinamismos de morte, de negação do amor e da vida. A auto-suficiência humana (eu idolátrico) leva ao fechamento, que leva ao pecado e este leva à morte. Resumindo, viver segundo a carne não é viver, é morrer ( $\operatorname{Rm} 8,6.12 .13$ ).

A "vida segundo a carne" é o oposto do dinamismo da vida segundo o Espírito, que leva à vida, pois o Espírito é vida. Os sinais do Espírito, já vistos no item anterior, deixam claro que o espírito humano criado pelo Espírito de Deus é de liberdade $(\operatorname{Rm} 8,15)$, fortaleza e amor (2Tm 1,7), libertado das forças de morte. O dinamismo e a vida se acentuam. É vida segundo a vontade de Deus, com o dom da filiação que se expressa na fraternidade humana e na acolhida de dons (Gl 6,18). E o dom maior é o Amor, que permanece (1Cor 13). Ele é o princípio do dinamismo de vida, mostrando que a força da "pessoa espiritual" é a capacidade de amar (Rm 8,3-4).

Resumindo, a vida "segundo a carne" é anti-pneumática, inspirada e motivada pelas idolatrias e falsas seguranças, que alienam o ser humano:

\footnotetext{
${ }^{34}$ Seguiremos a Gustavo GUTIERREZ, em Beber em seu próprio poço. [original de 1983). São Paulo: Loyola, 2000, p. 75-79.
} 
espírito de escravidão, da não relação do amor (egoísmo), do anticristo (anti -Reino), do erro (não verdade). A vida segundo o espírito é inspirada pelo amor, que gera liberdade, torna as pessoas solidárias e cria comunidade.

Trata-se de duas inspirações. Com tudo isso, remetemos às palavras de G. Gutiérrez, há mais de trinta anos, porém atuais, segundo as quais a vida segundo o Espírito não significa uma "existência segundo a alma, contra o corpo ou privada dele", mas uma existência "de acordo com a vida, o amor, a paz, a justiça - os grandes valores do Reino de Deus - e contra a morte". ${ }^{35} \mathrm{~A}$ alternativa da espiritualidade não é a da alma contra o corpo, ou a do espírito contra a matéria. A grande escolha apresentada pela espiritualidade é entre a vida ou a morte.

\section{Experiências do Deus da vida fazem a Palavra falar}

Dizíamos no início deste artigo que a vida (profundidade humana, pessoal e coletiva) e Palavra são dois livros que se lêem e se comentam mutuamente. Queremos finalizar com alguns desafios que nosso tempo leva à Palavra, provocando-a para falar.

Estamos diante do que se convenciou chamar mudança de época. Tratase de um tsunami que tudo invade, um terremoto que tudo sacode, deixando irreconhecíveis lugares antes familiares. Mundo pós-moderno, globalização, novas tecnologias, perda dos meta-relatos, problemas ecológicos, conflitos religiosos, secularização, crise de instituições religiosas, agonia do cristianismo em muitas regiões do mundo. Luzes e sombras na nossa América Latina, como já detectado por Aparecida.

Dentro de tudo está a força do Espírito, disto não podemos duvidar. Segundo a intuição de Victor Codina, uma das tarefas teológicas atuais é resgatar a pneumatologia e perceber a ação do Espírito acontecendo em situações de clandestinidade. ${ }^{36}$ De forma especial, na luta dos pobres. Trata-se de um espírito de fortaleza, proteção e saúde frente a inúmeras situações de martírio. De onde tiram forças os indígenas que defendem sua terra? E o migrante que busca vida para si e sua família? Os jovens em situação de risco permanente, com as taxas alarmantes de homicídio juvenil ${ }^{37}$ Os pobres da terra, que se

\footnotetext{
${ }^{35}$ GUTIERREZ. Op. cit., p. 91.

${ }^{36}$ CODINA, Victor. "Entrevista: El Concilio Vaticano II en América Latina”. Novamerica, Rio de Janeiro, no 37, jan-mar 2013, p. 6-17.

${ }^{37}$ Cf. Julio Jacobo Waiselfisz. Mapa da Violência 2012. Os Novos Padrões da Violência Homi-
} 
casam, têm filhos, buscam a vida em situações desumanas de moradia, transporte e todo direito social?

Trata-se de experiências pessoais e de grupos humanos concretos que, em sua força e esperança, revelam a presença do Espírito da vida e levam a redescobrir o Espírito criador e recriador como alento vital de toda humanização. São experiências do Espírito do Senhor ressuscitado, acontecendo na clandestinidade, em espaços não confessionais, em religiões diversas. Experiências pessoais e lutas coletivas questionam e convidam a abrir novos diálogos com as Escrituras, para que elas possam então falar, iluminar e encher de sentido situações antes silenciadas. São caminhos para adentrar a eterna novidade do Espírito, atestada nas Escrituras, nesta nossa única história de salvação.

Afinal, o Espírito ensinará o que ainda não podemos entender.

A fé na presença do Espírito do Senhor Ressuscitado, Livro vivo, na humanidade, na história e no cosmos não pode menos do que encher de esperança toda teologia e toda espiritualidade - compreendida sem dualismos, a verdadeira vida no Espírito.

\section{Conclusão}

1. A gravidade da separação entre espiritualidade e Bíblia não está na dispensa de um livro, mas da novidade de Cristo, de quem a Bíblia fala e a quem leva. A espiritualidade cristã, sem a novidade da Encarnação, que refaz a noção de Deus Amor Trindade, pode cair em espiritualidades alienantes e mesmo destrutivas do humano e da própria noção de história e de mundo.

2. O testemunho místico de Santa Teresa de Jesus nos fala do seu encontro com Cristo, Livro vivo, num contexto de proibição da leitura bíblica. Admirável experiência que realiza a finalidade mesma da Escritura, a vida, ao passo que aponta para uma necessária qualidade de leitura da Bíblia, que relacione Palavra e vida. Não uma leitura meramente conceitual, mecânica ou exterior que não toca nem transforma o cristão ou a comunidade. A mística é instância crítica da potencialidade transformadora da espiritualidade. Sempre será preciso afirmar, contra toda tendência a sobrepor o "conhecimento" da Bíblia sobre esta relação, que se trata de um Livro vivo.

3. Entre a interioridade do cristão e a exterioridade da Palavra há uma relação dialógica, possibilitada pelo próprio Espírito de Cristo, água viva que cida no Brasil. $1^{\text {a }}$ Ed. São Paulo: Instituto Sangari, 2011, p. 70-79, in: http://mapadaviolencia. org.br/mapa2012.php . Acesso em 01.05.2013. 
jorra de ambos os poços: da interioridade e da Palavra. Desta forma, tanto a Palavra interpela a profundidade do sujeito, transformando-o e fazendo-o caminhar, quanto as perguntas que nascem do sujeito abrem as Escrituras. Coragem, verdade e esperança neste diálogo são fundamentais. O Espírito está presente no alento de vida que brota da profundeza humana, mas também nas perguntas que emanam de toda luta de vida, mesmo na "clandestinidade": onde a vida sufocada não é por isso "desistida", mas "lutada". Os círculos bíblicos tanto trabalharam e trabalham nesta perspectiva. Assim sendo, não é possível falar, de quem "sabe da vida", que "não sabe nada da Bíblia"; ao contrário, o desafio é muito menos "ensinar" do que possibilitar que se faça a relação entre ambas.

4. Infelizmente, nem sempre a novidade bíblica fecundou a espiritualidade cristã, como bem mostra a história apresentada. A espiritualidade sofreu duas deturpações principais: a redução à interioridade individual e afetiva; e a concentração no aspecto não material da existência. No entanto, a perspectiva bíblica mostra claramente que o Espírito não se dissocia das dimensões corpórea, material, histórica, social e cósmica da vida. Ao contrário, Ele as anima, renova, vivifica, transforma. Espiritualidades desintegradoras das dimensões e relações humanas são anti-pneumáticas. A contemplação do Espírito e da "vida segundo o Espírito" na Bíblia apresenta-se como instância crítica desta tentação presente ainda em comunidades e grupos: a de "espiritualizar" (unilateralmente) o que Deus preferiu encarnar.

5. A espiritualidade cristã se nutre da esperança do Espírito. São necessários olhos para ver e se engajar nas novidades de Deus, neste tempo desafiador, em que as estruturas conhecidas parecem não responder mais aos anseios e necessidades das pessoas e dos povos, de forma especial os pobres. Iniciativas nascem de onde nem sempre se espera. Brotam do coração onde habita Deus e se expressam em realidades de resistência de povos e grupos marginalizados, em lutas de defesa da vida e da terra, em experiências de solidariedade, em formas de perdão que possibilitam o recomeço de povos feridos pelas guerras, em experimentos de interculturalidade que almejam a diversidade na unidade, na prioridade dada à cultura do diálogo, em pesquisas em prol da vida e do planeta, e em tantas outras ousadias de grupos, povos e religiões diversos, que enriquecem a perspectiva e a esperança cristãs.

6. O Espírito do Cristo Ressuscitado, Livro vivo, presente na humanidade, na história e no cosmos faz, destas realidades de vida em meio às forças da morte, um livro vivo das misericórdias de Deus. 


\section{Referências Bibliográficas}

ALVAREZ, T. "Santa Teresa maestra de vida espiritual". In: Estudios Teresianos. v.III. Burgos: Monte Carmelo, 1996, p. 333-351 [publicado por primeiro em: Confer 80 [1982] 685-702].

ANDRES MARTIN, M. La Teología Española en el siglo XVI. Madrid: BAC, 1977, v. II, p. 615.

BERNARD, C. A. Introdução à Teologia Espiritual. São Paulo: Loyola, 1999.

CASTRO, S. "Mística y cristología en Santa Teresa". Revista de Espiritualidad 56 (1997) 75-117.

CODINA, V. “Não extingais o Espírito” $(1 T s 5,19)$. Iniciação à Pneumatologia. São Paulo: Paulinas, 2010.

. "Entrevista: El Concilio Vaticano II en América Latina". Novamerica, Rio de Janeiro, $\mathrm{n}^{\circ}$ 37, jan-mar 2013, p. 6-17.

CONCÍLIO VATICANO II. Decreto Ad Gentes. In: <http://www.vatican. va/archive/hist_councils/ii_vatican_council/documents/vat-ii_ decree_19651207_ad-gentes_po.html>. Acesso em 01/05/2013.

CONGAR, Y. Revelação e experiência do Espírito. 2. ed. São Paulo: Paulinas, 2009.

GARCIA MATEO, R. Lo Spírito Santo nella vitta spirituale. Roma: Pontificia Università Gregoriana, [ap.], 2001.

GARCIA RUBIO, A. Unidade na pluralidade. O ser humano à luz da fé e da reflexão cristãs. 4. ed., São Paulo: Paulus, 2006.

GUTIERREZ, G. Beber em seu próprio poço. Itinerário espiritual de um povo. São Paulo: Loyola, 2000.

. O Deus da vida. 3. ed. São Paulo: Loyola, 2004.

HERRAIZ, M. "Biblia y espiritualidad teresiana”. Monte Carmelo 88 (1980) 305-334.

JOÃO PAULO II. Exortação Apostólica Pós-Sinodal Ecclesia in America. In: $<$ http://www.vatican.va/holy_father/john_paul_ii/apost_exhortations/ documents/hf_jp-ii_exh_22011999_ecclesia-in-america_po.html>. Acesso em 01/05/2013. 
KONINGS, J. "Interpretar a Bíblia aos cinquenta anos do Concílio Vaticano II". Perspectiva Teológica 44 (2012) 237-256.

LADARIA, L. F. El Dios vivo y verdadero: El misterio de la Trinidad. Salamanca: Secretariado Trinitario, 1998.

LLAMAS, R. "Santa Teresa y su experiencia de la Sagrada Escritura". Teresianum 33 (1982) 447-513.

. "Teresa de Jesús, testigo de la Palabra de Dios". Revista Teresa de Jesús: Temas Teresianos. Ávila, 1987, p. 67-78. Número especial.

MARTÍN VELASCO, J. El fenómeno místico. Estudio comparado. Madrid: Trotta, 1999.

MESTERS, C. Descobrir e discernir o rumo do espírito: uma reflexão a partir da Bíblia. In: FABRI DOS ANJOS, Márcio (Org.). Sob o fogo do Espirito. São Paulo: Paulinas/SOTER, 1998, p. 81-112.

PABLO MAROTO. D. "Santa Teresa y el protestantismo español”. Revista de Espiritualidad 40 (1981) 277-309.

PEDROSA-PADUA, L. Evolucionismo e espiritualidade: contribuições da mística para uma revisão da imagem de Deus. In: GARCIA RUBIO, A.; AMADO, J. P. Fé cristã e pensamento evolucionista. Aproximações teológico-pastorais a um tema desafiador. São Paulo: Paulinas, 2012, p. 221-253.

- Evangelizar uma cultura violenta. In: Violência, sociedade e cultura. Cadernos CERIS. Vozes/ Paulus/Loyola/ Paulinas/ CERIS, 2001, p.35-56.

ROVIRA BELloso, J. M. Tratado de Dios, uno y trino. Salamanca: Secretariado Trinitario, 1998.

SCHNEIDERS, S. "Theology and spirituality: strangers, rivals or partners?" Horizons 13/2 (1986) 253-274.

SECONDIN, B.; GOFFI, T. (Orgs.). Curso de Espiritualidade: experiência, sistemática, projeções. São Paulo: Paulinas, 1994.

TELLECHEA, G.I. "La censura inquisitorial de Biblias de 1554". Anthologica Аппиа 10 (1962) 89-142. 
TERESA DE JESUS. Livro da Vida. In: Teresa de Jesus. Obras Completas [texto estabelecido por Tomás Álvarez]. São Paulo: Carmelitanas/ Loyola, 1995.

TERESA DE JESUS. Poesias. In: TERESA DE JESUS. Obras Completas [texto estabelecido por Tomás Álvarez]. São Paulo: Carmelitanas/ Loyola, 1995.

Von BALTHASAR, H. U. Teologia y santidad. In: Ensayos Teologicos. Vol. I: Verbum Caro, Madrid: Ediciones Cristiandad, 1964, p. 235-268.

WAISELFISZ, J. J. Mapa da Violência 2012. Os Novos Padrões da Violência Homicida no Brasil. $1^{a}$ Ed. São Paulo: Instituto Sangari, 2011. In: $<$ http:// mapadaviolencia.org.br/mapa2012.php>. Acesso em 01.05.2013.

\section{Lúcia Pedrosa-Pádua}

Doutora em Teologia pela PUC-Rio Professora de Teologia na PUC-Rio, com pesquisa nas áreas de antropologia, mística e espiritualidade Rio de Janeiro/RJ - Brasil E-mail: lpedrosa@puc-rio.br

Recebido em: 11/11/13 Aprovado em: 18/11/13 